\title{
Recovery of Uranium and Plutonium from Waste Matrices Using Supercritical Fluid Extraction
}

\author{
Krishnamurthy Sujatha, Kancharlapalli Chinaraga Pitchaiah, Nagarajan Sivaraman*, \\ Thandankorai Ganapathi Srinivasan, Polur Ranga Rao Vasudeva Rao \\ Chemistry Group, Indira Gandhi Centre for Atomic Research, Kalpakkam, India \\ Email: ${ }^{*}$ sivaram@igcar.gov.in
}

Received October 19, 2012; revised November 19, 2012; accepted November 29, 2012

\begin{abstract}
Supercritical fluid extraction (SFE) of plutonium in its nitrate form from actual waste, i.e. plutonium bearing cellulose matrix was demonstrated using 0.1 litre capacity extraction vessel. Complete recovery of plutonium was demonstrated using modified supercritical carbon dioxide $\left(\mathrm{Sc}-\mathrm{CO}_{2}\right)$, i.e. $\mathrm{Sc}-\mathrm{CO}_{2}$ containing octylphenyl-N, N-diisobutyl-carbamoylmethylphosphine oxide ( $\phi \mathrm{CMPO}$ ). Near complete recovery of uranium was demonstrated from simulated waste matrices, i.e. uranium bearing teflon, glass and cellulose matrices using preparative scale SFE, i.e. from 1 litre capacity extraction vessel. The recovery of uranium was established using $\mathrm{Sc}-\mathrm{CO}_{2}$ modified with acetyl acetone.
\end{abstract}

Keywords: Supercritical $\mathrm{CO}_{2}$; SFE; Uranium; Plutonium; $\phi \mathrm{CMPO}$; Cellulose Matrix

\section{Introduction}

In recent years, Supercritical fluid extraction (SFE) has emerged as a powerful technique in the extraction of various metal ions from diverse waste matrices and as an alternative technique to solvent extraction. Liquid like density and gas like transport properties of supercritical fluids make them unique to act as special solvents. Supercritical fluids offer faster, efficient and cleaner extraction of compounds of interest with minimum generation of secondary liquid waste as $\mathrm{CO}_{2}$ escapes as gas after the extraction, leaving the solute in its pure form [1-3]. $\mathrm{CO}_{2}$ has a low critical temperature $\left(31.2^{\circ} \mathrm{C}\right)$ and a moderate critical pressure of 73.8 bar. It is non-flammable, non-toxic and environmentally friendly. $\mathrm{CO}_{2}$ being a non polar molecule, can be mainly employed for the extraction of non-polar and moderately polar compounds. Direct extraction of metal ions with supercritical carbon dioxide $\left(\mathrm{Sc}-\mathrm{CO}_{2}\right)$ is not possible because of weak solute-solvent interactions and charge neutralization requirement [4]. The extraction of metal ions is achieved by modifying the properties of carbon dioxide, i.e. mixing carbon dioxide with appropriate extractants or chelating agents. A major requirement for the use of a ligand as chelating agent in SFE is that the ligand and resulting metal chelate should have sufficient solubility in Sc- $\mathrm{CO}_{2}$ medium $[4,5]$.

Removal of various long lived radionuclides from

*Corresponding author. waste is of major concern in nuclear industry. Various organic materials such as polymers, rubbers and cellulose, widely used in nuclear industry and research facilities are prone to be contaminated with various radioactive materials. Several techniques such as solid phase extraction, solvent cleaning etc., are used for decontamination of radionuclide from waste matrices. However, these techniques result in the generation of secondary liquid waste, which requires further treatment. SFE is an alternative and attractive technique for recovery of actinides from such waste matrices since it reduces the generation of secondary liquid waste.

Supercritical carbon dioxide modified with ligands was employed for the extraction of various metal ions such as transition metal ions, lanthanides and actinides from different media [4-20]. The extraction of lanthanides and actinides was carried out using $\mathrm{Sc}-\mathrm{CO}_{2}$ modified with $\beta$-diketones [7]. Supercritical fluid extraction of uranium and plutonium from nitric acid medium was examined using Sc- $\mathrm{CO}_{2}$ containing tri-n-butyl phosphate (TBP) [8]. Quantitative dissolution of uranium dioxide in $\mathrm{Sc}-\mathrm{CO}_{2}$ containing TBP with nitric acid was reported [9-10]. Uranium dioxide and its solid solutions with neptunium, plutonium and americium dioxides were dissolved using $\mathrm{Sc}-\mathrm{CO}_{2}$ modified with $\mathrm{TBP} /$ nitric acid [11]. Supercritical fluid extraction of plutonium and americium from surrogate soil was investigated using Sc- $\mathrm{CO}_{2}$ modified with theonyltrifluoroacetone (TTA) and TBP [12]; the extraction efficiencies of Pu and Am 
were found to be $69 \%$ and $88 \%$, respectively. Sc- $\mathrm{CO}_{2}$ containing hexafluoroacetylacetone and pyridine was employed for the removal of actinides from stainless steel surface [13].

Complete removal of uranium from simulated solid waste matrices, e.g. tissue paper matrix was demonstrated in our laboratory using modified $\mathrm{Sc}-\mathrm{CO}_{2}$ [18]. In our earlier studies, complete recovery of plutonium from simulated waste matrices such as tissue, glass, teflon and stainless steel was demonstrated using $\mathrm{Sc}-\mathrm{CO}_{2}$ modified with octylphenyl-N, N-diisobutyl-carbamoylmethylphosphine oxide ( $\phi$ CMPO) in methanol [19]. In all these investigations, an analytical scale SFE was carried out, i.e. extraction from $1 \mathrm{~mL}$ capacity vessel. The actual waste generated in the laboratory, when subjected to SFE for the recovery of actinides resulted in an incomplete extraction. It was observed that the extraction efficiency of actinides from actual waste matrices (e.g. cellulose matrix) was highly influenced by the parameters such as storage period, nature of actinide species, moisture content etc.

In the present study, SFE of plutonium was carried out from the actual waste i.e. cellulose based waste matrix using a 0.1 litre capacity extraction vessel. The extraction efficiency was investigated as a function of ligand and its content in modifier, temperature, $\mathrm{HNO}_{3}$ content in the Sc- $\mathrm{CO}_{2}$ phase and extraction time. Initially the recovery of plutonium was carried out using a $1 \mathrm{~mL}$ extraction vessel and methods were evolved for the complete removal of plutonium from actual cellulose matrix. Subsequently, the plutonium bearing waste was processed using a 0.1 litre capacity extraction vessel. Similarly, the recovery of uranium was investigated in a preparative scale SFE facility, extraction vessel of 1 litre capacity. The recovery of uranium was investigated from different simulated waste matrices viz., cellulose, teflon and glass, which are generally encountered in various process steps in a radioactive laboratory. The results on the recovery of actinides from these waste matrices are discussed.

\section{Experimental}

\subsection{Lab Scale SFE System Employed for the Recovery of Plutonium from Actual Waste}

The SFE system (M/S Jasco) used consists of two reciprocating pumps, one with peltier cooling for pumping carbon dioxide and another pump for the delivery of modifier, a constant temperature oven $\left( \pm 1^{\circ} \mathrm{C}\right)$ and a backpressure regulator. Carbon dioxide gas used was of supercritical grade i.e. 99.9\%. The SFE system was setup in a glove box for the recovery of plutonium from waste matrices [20]. Extraction vessels of $1 \mathrm{~mL}$ and 0.1 litre capacities were employed for loading the sample. The 0.1 litre capacity $(11 \mathrm{~cm}$ height $\times 4 \mathrm{~cm} \mathrm{dia)}$ extraction vessel was designed and fabricated at our labo- ratory. The glove box facility was developed incorporating modifications required for handling high pressures and isolated electrical connections. A secondary container accommodated the primary extraction vessel so that any accidental pressure release can be contained causing no disturbance to the maintenance of an appropriate negative pressure of the glove box. Various in-built safety measures and associated alarm annunciation facilities were established to avoid over-pressurising of the system during its operation [20]. The two pumps used for the delivery of liquid carbon dioxide and the modifier (extractant in methanol) were placed outside the glove box. However the backpressure regulator and heating oven, which accommodated the extraction vessel were kept inside the glove box. The "extracted sample collection system" was also arranged inside the glove box and plutonium was sampled for assay.

In the initial experiments, $1 \mathrm{~mL}$ capacity extraction vessel was employed to optimize the SFE conditions for efficient recovery of plutonium from waste matrix. The cellulose based matrix containing plutonium in its nitrate form was cut into small pieces, typical dimension being 5 $\times 10 \mathrm{~cm}$. The cut pieces were inserted into a $1 \mathrm{~mL}$ extrac-

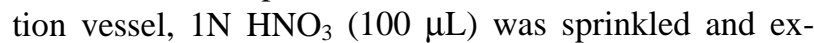
traction was carried out under typical conditions viz., pressure: 250 bar, temp: $45^{\circ} \mathrm{C}, \mathrm{Sc}-\mathrm{CO}_{2}$ flow rate: 3 $\mathrm{mL} / \mathrm{min}$, methanol flow rate: $0.15 \mathrm{~mL} / \mathrm{min}$; ligand content: 5 wt\% ligand in methanol, about $1.8 \mathrm{~mL}$ of $\mathrm{HNO}_{3}$ added to $100 \mathrm{~mL}$ solution of methanol containing suitable ligand. The extraction was carried out for a period of 2 hrs. The plutonium present in extract was collected in small volume of dil. $\mathrm{HNO}_{3}+$ isopropanol medium. The plutonium contents of the extract after the SFE experiment was assayed by liquid scintillation technique. The remains i.e. un-extracted plutonium in cellulose waste


leaching efficiency using ultrasonication was established earlier in our laboratory and was found to be $>98 \%$ [19]. After the initial studies, the plutonium bearing waste was taken after cutting it into small pieces in to a 0.1 litre SFE vessel and extraction was carried out.

\subsection{Experiments with Preparative Scale SFE System}

The supercritical fluid extraction system (M/S Inexus) consisted of the following: high pressure $\mathrm{CO}_{2}$ pump capable of delivering carbon dioxide up to $200 \mathrm{~g} / \mathrm{min}$, chiller for circulating coolant through carbon dioxide pump head, co-solvent pump for the delivery of acetyl acetone dissolved in methanol, high pressure extraction vessel of 1 litre capacity, back pressure regulator and high pressure fraction collection vessel. Carbon dioxide was delivered with a typical flow rate of $40 \mathrm{~g} / \mathrm{min}$ whereas modifier (acetyl acetone dissolved in methanol) 
was delivered at a flow rate of $1-2 \mathrm{~mL} / \mathrm{min}$. Typical pressure employed for the recovery of uranium from cellulose waste was 200 bar and extraction was carried out at $50^{\circ} \mathrm{C}$. The extracts were collected in $0.01 \mathrm{~N} \mathrm{HNO}_{3}$. The simulated uranium waste from cellulose, teflon and glass matrices was prepared by spiking known quantities ( $\sim 2$ grams) uranyl nitrate onto these matrices followed by drying at room temperature for about 24 hrs. About 90\% volume of the 1 litre capacity extraction vessel was filled with simulated waste matrices. The uranium content in the extract and the remains were analysed by HPLC technique using reversed phase chromatographic technique [21].

\section{Results and Discussion}

\subsection{Recovery of Plutonium from Actual Waste}

In our earlier studies, we have demonstrated complete recovery (>99 \%) of plutonium in its $\mathrm{Pu}(\mathrm{IV})$ nitrate form from simulated waste matrices (paper, glass, stainless steel and teflon) using Sc- $\mathrm{CO}_{2}$ modified with $2 \mathrm{wt} \%$ $\phi$ CMPO in methanol containing $0.16 \mathrm{~N} \mathrm{HNO}_{3}$ under supercritical experimental conditions [19]. Simulated waste containing plutonium stored for several months require addition of nitric acid for its effective removal. Supercritical fluid extraction of plutonium was subsequently carried out from actual waste, which was generated over a period of 5 years. However, the above SFE procedure, when applied to the actual waste resulted in only $~ 70 \%$ recovery, emphasizing the fact that the procedure needs modification depending upon the physical conditions to which the actual waste was subjected to as they are responsible for the degree of interaction with tissue paper matrix. The incomplete extraction behaviour suggested a possible chemical binding between cellulose present in tissue matrix with plutonium. In our earlier studies, we have established evidence for the enhanced chemical interaction of actinide ions (e.g. uranyl nitrate) with cellulose and dextrose matrix. The cellulose is polyhydroxy compound, which can possibly interact with plutonium/uranium and form compounds through exchange of " $\mathrm{H}$ " in the hydroxide group. Thus the poor extraction of plutonium present in the long-time stored cellulose waste can be attributed to the possible formation of some non-extractable species. Hence investigations were carried out in the present study to overcome the plutonium-matrix interaction as well as to convert the plutonium into its soluble species, nitric acid was added to the modified Sc- $\mathrm{CO}_{2}$ phase; similarly, nitric acid was also sprinkled onto the matrix prior to the extraction of plutonium. To improve the plutonium recovery from waste matrix, extraction efficiency was investigated as a function of 1) ligand and its content in modifier; 2) $\mathrm{HNO}_{3}$ content in mobile $\mathrm{CO}_{2}$ phase; 3) temperature; and also 4) extraction time.
Recovery of plutonium from cellulose waste was carried out using 2 - $5 \mathrm{wt} \%$ $\phi \mathrm{CMPO}$ in methanol; similarly, $\mathrm{HNO}_{3}$ concentration was varied from 0.16 to $0.8 \mathrm{~N}$. Subsequently, $\mathrm{Sc}-\mathrm{CO}_{2}$ modified with various ligands such as $\phi \mathrm{CMPO}$, TBP, acetyl acetone, trifluoroacetyl acetone and TTA were employed. In these experiments, the cellulose based matrix was cut into small pieces, the cut piece was placed into a $1 \mathrm{~mL}$ extraction vessel, $1 \mathrm{~N}$ $\mathrm{HNO}_{3}(100 \mu \mathrm{L})$ was sprinkled and extraction was carried out using suitable experimental conditions and the results are shown in Table 1. The typical experimental conditions were, pressure: 250 bar, temp: $45^{\circ} \mathrm{C}, \mathrm{Sc}-\mathrm{CO}_{2}$ flow rate: $3 \mathrm{~mL} / \mathrm{min}$, modifier (5 $\mathrm{wt} \%$ ligand in methanol with $1.8 \mathrm{~mL}$ of $\mathrm{HNO}_{3}$ ) flow rate: $0.15 \mathrm{~mL} / \mathrm{min}$. The extraction was carried out for a period of 2 hours. The maximum plutonium recovery was found to be $\sim 99.8 \%$ when

Table 1. Recovery of plutonium from cellulose based waste matrix; (a) Influence of $\phi \mathrm{CMPO}$ concentration; (b) Influence of $\mathrm{HNO}_{3}$ concentration; (c) Influence of ligands.

(a)

\begin{tabular}{|c|c|c|}
\hline S. No. & $\begin{array}{c}\text { Sc- } \mathrm{CO}_{2} \text { modified } \phi \mathrm{CMPO} \\
\text { containing } 0.3 \mathrm{~N} \mathrm{HNO}(\mathrm{wt} \% \\
\phi \mathrm{CMPO})\end{array}$ & Plutonium recovery ${ }^{*}(\%)$ \\
\hline 1 & 2 & $65-80$ \\
\hline 2 & 3 & $69-85$ \\
\hline 3 & 4 & $71-90$ \\
\hline 4 & 5 & $86-99.8$ \\
\hline
\end{tabular}

*6 independent experiments with each concentration performed modifier ( $\phi$ CMPO in methanol); Sample: Pu from cellulose matrix kept in $1 \mathrm{~mL}$ vessel; Sc- $\mathrm{CO}_{2}$ : $3 \mathrm{~mL} / \mathrm{min}$, modifier: $0.15 \mathrm{~mL} / \mathrm{min}$, P: 250 bar, Temp.: $45^{\circ} \mathrm{C}$.

(b)

\begin{tabular}{ccc}
\hline S. No. & $\begin{array}{c}\text { Sc- } \mathrm{CO}_{2} \text { modified with } 5 \text { wt\% } \phi \mathrm{CMPO} \text { in } \\
\text { methanol } \mathrm{HNO}_{3} \text { (molarity) used }\end{array}$ & $\begin{array}{c}\text { Plutonium recovery } \\
\text { (\%) }\end{array}$ \\
\hline 1 & 0.16 & 84 \\
2 & 0.3 & 99 \\
3 & 0.5 & 96 \\
4 & 0.8 & 90 \\
\hline
\end{tabular}

*Average of three independent experiments; Sample: Pu from cellulose matrix present in $1 \mathrm{~mL}$ vessel; $\mathrm{S}_{\mathrm{C}}-\mathrm{CO}_{2}: 3 \mathrm{~mL} / \mathrm{min}$, modifier: $0.15 \mathrm{~mL} / \mathrm{min}, \mathrm{P}$ : 250 bar, Temp.: $45^{\circ} \mathrm{C}$.

(c)

\begin{tabular}{ccc}
\hline S. No. & $\begin{array}{c}\mathrm{Sc}_{2} \mathrm{CO}_{2} \text { modified with } \\
\text { ligand }\end{array}$ & $\begin{array}{c}\text { Maximum plutonium } \\
\text { recovery (\%) }\end{array}$ \\
\hline 1 & CMPO & 99.8 \\
2 & TBP & 73 \\
3 & TTA & 78 \\
4 & F $_{3}$ acac & 63 \\
5 & acac & 34 \\
\hline
\end{tabular}

$F_{3}$ acac: trifluoro acetyl acetone; acac: acetyl acetone; Experimental conditions: Sc- $\mathrm{CO}_{2}: 3 \mathrm{~mL} / \mathrm{min}$; modifier (5 wt\% ligand in methanol): $0.15 \mathrm{~mL}$ min; Temp: $45^{\circ} \mathrm{C}$; Pressure: 250 bar. 
Sc- $\mathrm{CO}_{2}$ modified with $5 \mathrm{wt} \% \phi \mathrm{CMPO}$ in methanol containing $0.3 \mathrm{~N} \mathrm{HNO}_{3}$ was employed. Sc- $\mathrm{CO}_{2}$ modified with TBP resulted in a maximum plutonium recovery of about $73 \%$, whereas extraction with TTA resulted in a recovery of about $78 \%$. Extraction with trifluoroacetyl acetone resulted in $\sim 63 \%$ recovery whereas extraction with acetyl acetone resulted only in about 34\%. 25 independent experiments were performed to establish the extraction efficiency of plutonium from waste using Sc- $\mathrm{CO}_{2}$ modified with $\phi \mathrm{CMPO}$. The extraction efficiency was found to vary from $88 \%$ to $99.8 \%$ in these experiments, averaging about $96 \%$ (Figure 1). The total amount of plutonium in the cut-piece $(4 \times 10 \mathrm{~cm})$ was varying from $10 \mu \mathrm{g}$ to $60 \mu \mathrm{g}$. Hence $\phi \mathrm{CMPO}$ was chosen as the ligand for the recovery of plutonium from the bulk cellulose waste.

The extraction efficiency of plutonium recovery from cellulose matrix was also studied at $45^{\circ} \mathrm{C}, 50^{\circ} \mathrm{C}$ and $55^{\circ} \mathrm{C}$; similary, extraction was also carried out at pressure 200 and 250 bar; there was no significant change in the extraction efficiency of plutonium in these studies.

The cellulose waste with plutonium was taken up in a 0.1 litre capacity extraction vessel and SFE was carried out using $\mathrm{Sc}-\mathrm{CO}_{2}$ modified with $5 \mathrm{wt} \% \phi \mathrm{CMPO}$ in methanol. The plutonium bearing cellulose waste was processed in five different batches; SFE was carried out for about 40 to 80 hrs duration; after every 5 hrs, the vessel was opened and fresh $\mathrm{HNO}_{3}(1 \mathrm{~N})$ was sprinkled on to the waste followed by SFE to improve the extraction efficiency. Typical result from a particular batch is shown in Figure 2. About $30 \mathrm{mg}$ of plutonium was recovered from cellulose waste matrix during these five campaigns.

The extraction from 0.1 litre extraction vessel needed longer duration because of the low pumping rate of $\mathrm{CO}_{2}$

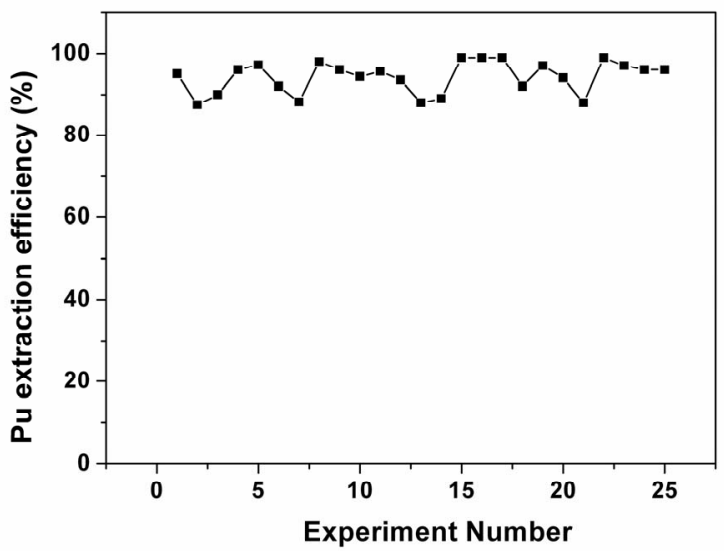

Figure 1. Recovery of plutonium from actual cellulose waste matrix using SFE. Experimental Conditions: $\mathrm{Sc}_{-} \mathrm{CO}_{2}: 3$ $\mathrm{mL} / \mathrm{min}$; modifier (5 $\mathrm{g} \phi \mathrm{CMPO}$ and $1.8 \mathrm{~mL} 16 \mathrm{~N} \mathrm{HNO}_{3}$ in 100 mL methanol): 0.15 mL/min; P: 250 bar; Temperature: $45^{\circ} \mathrm{C}$. Extraction period: 2 hours; Extraction vessel capacity: $1 \mathrm{~mL}$. Sample: cellulose waste containing plutonium.

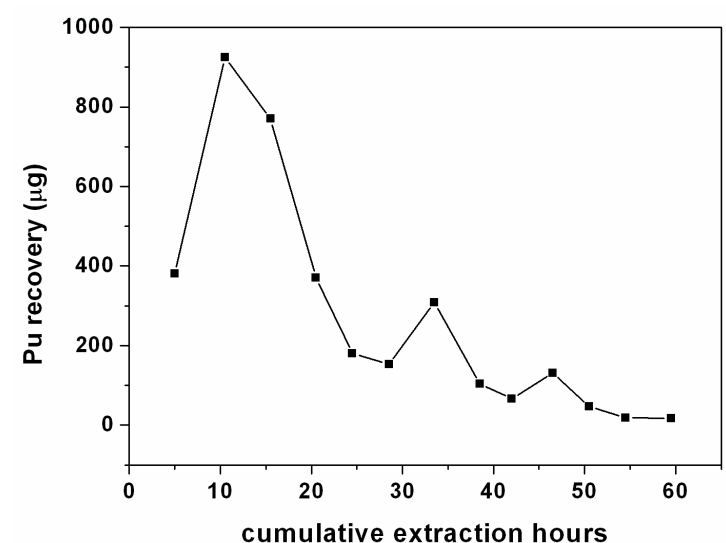

Figure 2. Extraction and recovery of plutonium from cellulosic waste matrix. Sc- $\mathrm{CO}_{2}: 3.5 \mathrm{~mL} / \mathrm{min}$; modifier: (5 g $\phi C M P O$ and $1.8 \mathrm{~mL} 16 \mathrm{~N} \mathrm{HNO}_{3}$ in $100 \mathrm{~mL}$ methanol): 0.15 $\mathrm{mL} / \mathrm{min}$; P: 200 bar, Temp: $50^{\circ} \mathrm{C}$, Extraction vessel capacity: 0.1 litre; Sample: cellulose waste containing plutonium ( $3.5 \mathrm{mg}$ of plutonium was recovered in this batch).

i.e. only a maximum flow rate of $3.5 \mathrm{~mL} / \mathrm{min}$ was employed with the existing SFE facility. Extraction kinetics was found to be slow because $\sim 30$ minutes are required to affect one $\mathrm{CO}_{2}$ change in the extraction vessel. A facility for higher flow rates e.g. 25 - $50 \mathrm{~mL} / \mathrm{min}$ is essential for a faster extraction and recovery.

The delivery of $\phi C \mathrm{CMPO}$ into $\mathrm{CO}_{2}$ phase in the absence of co-solvent, e.g. methanol results in further reduction of secondary liquid waste, an added advantage to SFE technique. It may be also useful to minimize the phase perturbation, if co-solvent (e.g. methanol) is not added, which will preserve the integrity of supercritical fluid phase of carbon dioxide. In our earlier studies [22] we have demonstrated the co-solvent free addition of various ligands to $\mathrm{Sc}-\mathrm{CO}_{2}$ for extraction of metal ions. In the present study, $\phi \mathrm{CMPO}$ was added to $\mathrm{Sc}-\mathrm{CO}_{2}$ and the modified phase was employed for the recovery of Plutonium from cellulose waste matrix (Figure 3).

Near complete recovery of plutonium from waste was established in these studies from a $1 \mathrm{~mL}$ capacity extraction vessel. These studies have established the potential use of co-solvent free delivery of ligands for larger scale supercritical fluid extraction and recovery of actinides from waste matrices.

\subsection{Recovery of Uranium from Simulated Waste Matrices Using Preparative Scale SFE Facility}

The results on the extraction and recovery of uranyl ion from various matrices are shown in Table 2. Sc- $\mathrm{CO}_{2}$ modified with methanol containing acetyl acetone was employed for the recovery of uranium. The uranium bearing cellulose matrix was dried at about $50^{\circ} \mathrm{C}$ for about 20 minutes in the extraction vessel prior to SFE. 
Highest recovery of uranyl ion, i.e. 99\% was observed from teflon and glass matrices. The extraction efficiency was found to be $\sim 80 \%$ - $83 \%$ from cellulose matrix when Sc- $\mathrm{CO}_{2}$ was delivered at flow rate of $30 \mathrm{~g} / \mathrm{min}$ with a modifier (3 wt\% acetyl acetone in methanol) flow rate of $1 \mathrm{~mL} / \mathrm{min}$ at 200 bar pressure. In these studies, four

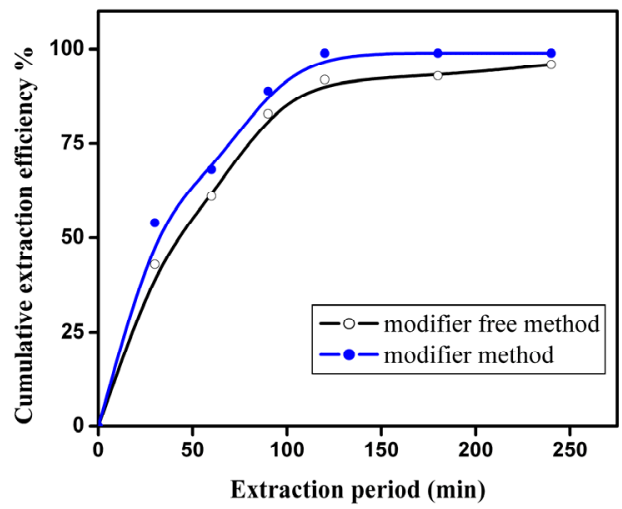

Figure 3. Co-solvent-free delivery of $\phi \mathrm{CMPO}$ for supercritical fluid extraction and recovery of plutonium from cellulose waste matrix. Experimental: Sc- $\mathrm{CO}_{2}: 3 \mathrm{~mL} / \mathrm{min}$; $\mathbf{P}$ : 250 bar; Temperature: $45^{\circ} \mathrm{C}$; Extraction vessel capacity: 1 $\mathrm{mL}$; Sample: cellulose waste with plutonium. Co-solvent method: Modifier (5 g $\phi \mathrm{CMPO}$ and $1.8 \mathrm{~mL} 16 \mathrm{~N} \mathrm{HNO}_{3}$ in $100 \mathrm{~mL}$ methanol) flow rate: $0.15 \mathrm{~mL} / \mathrm{min}$; Co-solvent free method: $\phi C M P O$ (equilibrated with $4 \mathrm{~N}^{-N_{3}}{ }_{3}$ ) delivery $\sim 50$ mg/hr.

Table 2. Recovery of uranium from simulated waste matrices. In each run, $\sim 2$ g uranyl nitrate was loaded on to various matrices.

\begin{tabular}{|c|c|c|c|}
\hline Matrix & Experimental conditions & $\begin{array}{l}\text { Extraction } \\
\text { period } \\
\text { (dynamic } \\
\text { extraction) }\end{array}$ & $\begin{array}{l}\text { Extraction } \\
\text { /Recovery } \\
\quad(\%)\end{array}$ \\
\hline Teflon & $\begin{array}{l}\text { P: } 200 \text { bar; } \mathrm{T}: 50^{\circ} \mathrm{C} \text {; } \mathrm{Sc}-\mathrm{CO}_{2} \\
\text { flow rate: } 20 \mathrm{~g} / \mathrm{min} \text { Ligand } \\
\text { flow rate: } 1 \mathrm{~g} / \mathrm{min}(1 \mathrm{wt} \% \\
\text { acetyl acetone in methanol) }\end{array}$ & $4 \mathrm{hrs}$ & $97-99$ \\
\hline Glass & $\begin{array}{l}\text { P: } 200 \text { bar ; } \mathrm{T}: 50^{\circ} \mathrm{C} ; \mathrm{Sc}^{-\mathrm{CO}_{2}} \\
\text { flow rate: } 20 \mathrm{~g} / \mathrm{min} \text { Ligand } \\
\text { flow rate: } 1 \mathrm{~g} / \mathrm{min}(1 \mathrm{wt} \% \\
\text { acetyl acetone in methanol) }\end{array}$ & $4 \mathrm{hrs}$ & $>99$ \\
\hline \multirow{3}{*}{ Cellulose } & $\begin{array}{l}\mathrm{P}: 200 \text { bar; } \mathrm{T}: 50^{\circ} \mathrm{C}, \mathrm{Sc}-\mathrm{CO}_{2} \\
\text { flow rate: } 30 \mathrm{~g} / \mathrm{min} \text { Ligand } \\
\text { flow rate: } 1 \mathrm{~g} / \mathrm{min}(3 \mathrm{wt} \% \\
\text { acetyl acetone in methanol) }\end{array}$ & $4 \mathrm{hrs}$ & $\begin{array}{l}83 \\
80\end{array}$ \\
\hline & $\begin{array}{l}\mathrm{P}: 300 \text { bar; } \mathrm{T}: 50^{\circ} \mathrm{C}, \mathrm{Sc}-\mathrm{CO}_{2} \\
\text { flow rate: } 40 \mathrm{~g} / \mathrm{min} \text { Ligand } \\
\text { flow rate: } 1 \mathrm{~g} / \mathrm{min}(3 \mathrm{wt} \% \\
\text { acetyl acetone in methanol) }\end{array}$ & $7 \mathrm{hrs}$ & $\begin{array}{l}90 \\
93\end{array}$ \\
\hline & $\begin{array}{c}\mathrm{P}: 300 \text { bar; } \mathrm{T}: 50^{\circ} \mathrm{C} ; \mathrm{Sc}-\mathrm{CO}_{2} \\
\text { flow rate: } 40 \mathrm{~g} / \mathrm{min} \text { Ligand } \\
\text { flow rate: } 1 \mathrm{~g} / \mathrm{min}(6 \mathrm{wt} \% \\
\text { acetyl acetone in methanol })\end{array}$ & $4 \mathrm{hrs}$ & 80 \\
\hline
\end{tabular}

hours extraction was carried out for the recovery. In another set of experiments, the extraction was carried out at a $\mathrm{Sc}-\mathrm{CO}_{2}$ flow rate of $40 \mathrm{~g} / \mathrm{min}$ for about seven hours; the extraction efficiency was found to be between $90 \%$ 93\%. In another experiment, the concentration of acetyl acetone was doubled i.e. $6 \mathrm{wt} \%$ acetyl acetone in methanol and extraction was done for 4 hrs duration. In these experiments, extraction efficiency of about $80 \%$ $85 \%$ was achieved. The extraction profile for the recovery of uranium from cellulose matrix is shown in Figure 4. These studies have established that $\mathrm{Sc}-\mathrm{CO}_{2}$ flow rate and acetyl acetone composition in the methanol can be varied to achieve near complete recovery of uranium from waste matrix. The complete recovery of uranium from teflon and glass matrices ( 99\%) compared to cellulose matrix has established interaction between uranyl ion with cellulose matrix, leading to some reduction in the extraction efficiency under identical conditions.

Our future endeavors include minimization, recovery and reuse of extractans, which are employed with $\mathrm{CO}_{2}$ for the recovery of actinides from various waste matrices. Our future investigations include use of optimum/minimum pressure and temperature with the preparative scale SFE facility for the recovery of actinides from various matrices.

\section{Conclusion}

Preparative scale supercritical fluid extraction method was developed and demonstrated for the recovery of uranium from simulated waste matrices. Similarly, complete recovery of plutonium was demonstrated from actual cel-

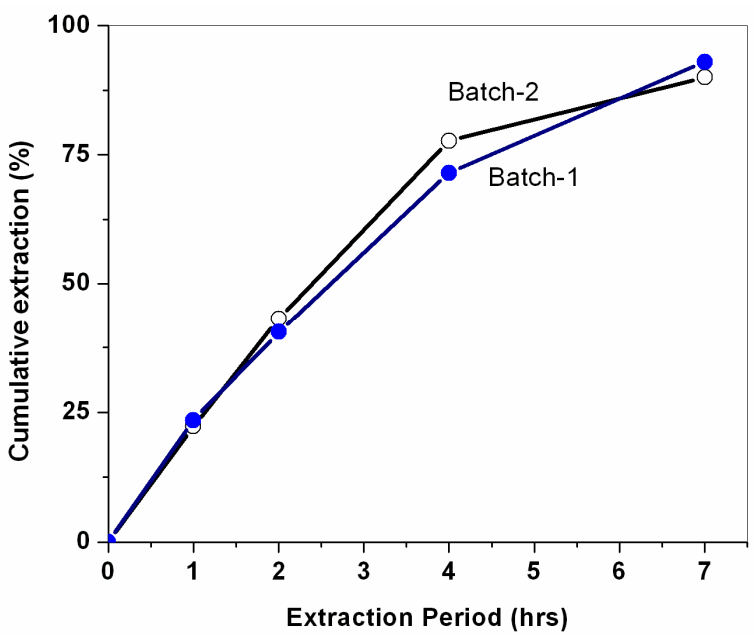

Figure 4. Supercritical fluid extraction and recovery of uranium from simulated cellulose waste matrix. Experimental conditions: P: 300 bar; Temp.: $50^{\circ} \mathrm{C}$; Sc- $\mathrm{CO}_{2}: 40 \mathrm{~g} / \mathrm{min}$; modifier: 3 wt \% acetyl acetone in methanol: $1 \mathrm{~mL} / \mathrm{min}$. Extraction vessel capacity: 1 litre; Sample: simulated cellulose waste containing uranium. 
lulose waste. These studies established that SFE basedtechnique provides an excellent alternative to recover the actinides with minimum generation of secondary liquid waste. The investigations to establish the complete extraction of actinides from waste matrices can lead to various other possible applications in the fuel cycle program.

\section{Acknowledgements}

T.G. Srinivasan would like to acknowledge with thanks The Department of Atomic Energy, India for the award of Raja Ramanna Fellowship.

\section{REFERENCES}

[1] M. Caude and D. Thiebaut, "Practical Supercritical Fluid Chromatography and Extraction," Harwood Academic Publishers, Switzerland, 1999.

[2] M. A. Mc-Hugh and V. J. Krukonis, "Supercritical Fluid Extraction: Principle and Practice,” 2nd Edition, Butterworth-Heinamann, Boston, 1994.

[3] C. Erkey, "Supercritical Carbon Dioxide Extraction of Metals from Aqueous Solutions: A Review,” Journal of Supercritical Fluids, Vol. 17, No. 3, 2000, pp. 259-287. doi:10.1016/S0896-8446(99)00047-9

[4] K. E. Laintz, C. M. Wai, C. R. Yonker and R. D. Smith, "Extraction of Metal Ions from Liquid and Solid Materials by Supercritical Carbon Dioxide," Analitical Chemistry, Vol. 64, No. 22, 1992, pp. 2875-2878. doi:10.1021/ac00046a039

[5] Y. Lin, N. G. Smart and C. M. Wai, "Supercritical Fluid Extraction and Chromatography of Metal Chelates and Organometallic Compounds," Trend Analitical Chemistry, Vol. 14, No. 3, 1995, pp. 123-133. doi:10.1016/0165-9936(95)94045-G

[6] C .M. Wai, "Supercritical Fluid Extraction of Trace Metals from Solid and Liquid Materials for Analytical Applications," Analitical Sciences, Vol. 11, No. 1, 1995, pp. 165-167. doi:10.2116/analsci.11.165

[7] Y. Lin, R. D. Brauer, K. E. Laintz and C. M. Wai, "Supercritical Fluid Extraction of Lanthanides and Actinides from Solid Materials with a Fluorinated $\beta$-Diketone,” Analitical Chemistry, Vol. 65, No. 18, 1993, pp. 25492551. doi:10.1021/ac00066a027

[8] S. Iso, S. Uno, Y. Meguro, T. Sasaki and Z. Yoshida, "Pressure Dependence of Extraction Behaviour of Plutonium (IV) and Uranium (VI) from Nitric Acid Solution to Supercritical Carbon Dioxide Containing Tributylphosphate,” Progress in Nuclear Energy, Vol. 37, No. 1-4, 2000, pp. 423-428. doi:10.1016/S0149-1970(00)00082-2

[9] O. Tomioka, Y. Meguro, Y. Enokida, I. Yamamoto and Z. Yoshida, "Dissolution Behaviour of Uranium Oxides with Supercritical $\mathrm{CO}_{2}$ Using $\mathrm{HNO}_{3}$-TBP Complex as a Reactant," Journal of Nuclear Science and Technology, Vol. 38, No. 12, 2001, pp. 1097-1102. doi:10.1080/18811248.2001.9715141

[10] Y. Meguro, S. Iso, Z. Yoshida, O. Tomioka, Y. Enokida and I. Yamamoto, "Decontamination of Uranium Oxides from Solid Wastes by Supercritical $\mathrm{CO}_{2}$ Fluid Leaching Method Using $\mathrm{HNO}_{3}$-TBP Complex as a Reactant," Journal of Supercritical Fluids, Vol. 31, No. 2, 2004, pp. 141147. doi:10.1016/j.supflu.2003.10.005

[11] T. I. Trofimov, M. D. Samsonov, Y. M. Kulyako and B. F. Myasoedov, "Dissolution and Extraction of Actinide Oxides in Supercritical Carbon Dioxide Containing the Complex of Tri- $n$-Butylphosphate with Nitric Acid,” Comptes Rendus Chimie, Vol. 7, No. 12, 2004, pp. 1209-1213. doi:10.1016/j.crci.2004.04.010

[12] B. J. Mincher, R. V. Fox, R. G. G. Holmes, R. A. Robbins and C. Boardman, "Supercritical Fluid Extraction of Plutonium and Americium from Soil Using Theonytrifluoroacetone and Tributylphosphate Complexation," Radiochimica Acta, Vol. 89, No. 10, 2001, pp. 613-617. doi:10.1524/ract.2001.89.10.613

[13] A. A. Murzin, V. A. Babain, A. Yu. Shadrin, V. A. Kamachev, V. N. Romanovskii, V. A. Starchenko, S. V. Podoinitsyn, Yu. A. Revenko, M. V. Logunov and N. G. Smart, "Deactivation in Sub and Supercritical Carbon Dioxide,” Radiochemistry, Vol. 44, No. 4, 2002, pp. 410415. doi:10.1023/A:1020641431291

[14] M. Shamsipur, A. R. Ghiasvand and Y. Yamini, "Extraction of Uranium from Solid Matrices Using Modified Supercritical Fluid $\mathrm{CO}_{2}$," Journal of Supercritical Fluids, Vol. 20, No. 2, 2001, pp. 163-169. doi:10.1016/S0896-8446(01)00052-3

[15] Y. Lin, C. M. Wai, F. M. Jean and R. D. Brauer, "Supercritical Fluid Extraction of Thorium and Uranium Ions from Solid and Liquid Materials with Fluorinated betaDiketones and Tributyl Phosphate," Environmental Science and Technology, Vol. 28, No. 6, 1994, pp. 11901193. doi:10.1021/es00055a034

[16] P. Kumar, A. Pal, M. K. Saxena and K. L. Ramakumar, "Supercritical Fluid Extraction of Uranium and Thorium from Solid Matrices,” Desalination, Vol. 232, No. 1-3, 2008, pp. 71-79. doi:10.1016/j.desal.2007.08.022

[17] A. Rao, P. Kumar and K. L. Ramakumar, "Separation of Uranium from Different Uranium Oxide Matrices Employing Supercritical Carbon Dioxide Extraction,” Journal of Radioanalytical Nuclear Chemistry, Vol. 285, No. 2, 2010, pp. 247-257. doi:10.1007/s10967-010-0568-7

[18] R. Kumar, N. Sivaraman, E. Senthil Vadivu, T. G. Srinivasan and P. R. Vasudeva Rao, "Complete Removal of Uranyl Nitrate from Tissue Matrix Using Supercritical Fluid Extraction,” Radiochimica Acta, Vol. 91, No. 4, 2003, pp. 197-201. doi:10.1524/ract.91.4.197.19966

[19] R. Kumar, N. Sivaraman, K. Sujatha, T. G. Srinivasan and P. R. Vasudeva Rao, "Removal of Plutonium and Americium from Waste Matrices by Supercritical Carbon Dioxide Extraction," Radiochimica Acta, Vol. 95, No. 10, 2007, pp. 577-584. doi:10.1524/ract.2007.95.10.577

[20] V. Suresh Kumar, R. Kumar, N. Sivaraman, G. Ravisankar and P. R. Vasudeva Rao, "Design and Adaptation of a Novel Supercritical Extraction Facility for Operation in a Glove Box for Recovery of Radioactive Elements," Review of Scientific Instruments, Vol. 81, No. 9, 2010, Article ID: 094101. doi:10.1063/1.3484190 
[21] A. Datta, N. Sivaraman, T. G. Srinivasan and P. R. Vasudeva Rao, "Liquid Chromatographic Behaviour of Actinides and Lanthanides on Monolith Supports," Radiochimica Acta, Vol. 99, No. 5, 2011, pp. 275-283.

[22] R. Kumar, N. Sivaraman, K. Sujatha, T. G. Srinivasan and P. R. Vasudeva Rao, "A Novel Technique for Modi- fier Free Delivery of Ligands for Supercritical Fluid Extraction," Radiochimica Acta, Vol. 97, No. 8, 2009, pp. 443-451. doi:10.1524/ract.2009.1633 